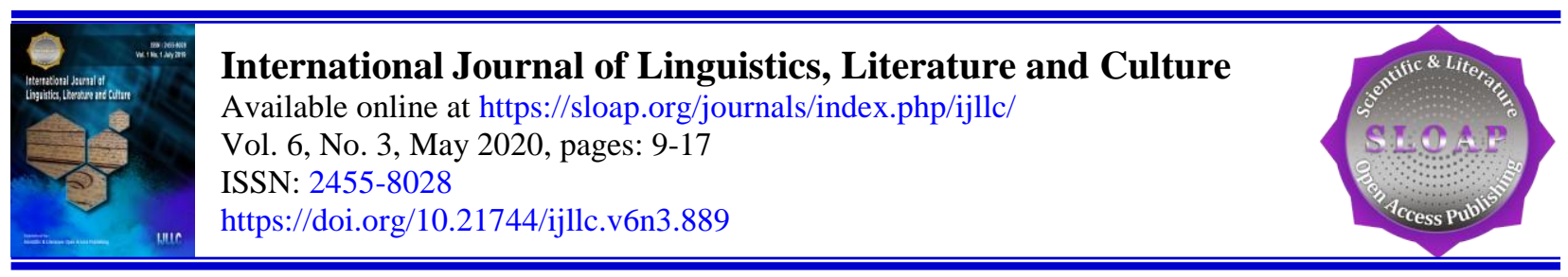

\title{
Adverb of Manner and Its Translations Found in the Novel "The Good Earth"
}

I Made Juliarta ${ }^{\text {a }}$

Article history:

Submitted: 18 January 2020

Revised: 19 February 2020

Accepted: 27 March 2020

\section{Keywords:}

adverb;

Chinese culture;

novel;

shifts;

variations;

\begin{abstract}
The novel the Good Earth is one of the popular novels that tell the story about Chinese culture. Some sentences contain an adverb of manner and its translation from English into Indonesian. The text is analyzed and viewed to find the translation of the adverb of manner. The purpose of this study is to analyze the source translation and get the meaning and its sentence. As we know that an adverb is a word that changes the meaning of a verb, adjective, and a sentence. Adverbs are words like hurriedly, quickly, slowly, and instantly. It modifies a verb or verb phrase. An adverb gives information about the manner, time, place, frequency, or certainty. Adverbials are words groups in which an adverbial phrase tells us something about the verb. They could be taken in the forms of adverbs, adverb phrases, temporal noun phrases or prepositional phrases. Some classifications of adverbial are found in the novel. It is called adverbial of manner. The research aims to find out the translation of manner adverb. The theory used is Brown and Miller (1992) describing that adverb of manner indicating how the event described by the verb. The adverb of manner shows how an action is performed. There are variations of its form. The aim of the study is: (i) to identify the form of adverb of manner and its translation in the novel The Good Earth into Bumi yang Subur. (ii) to analyze the types of shifts of relative clauses applied in the translation of The Good Earth into Bumi yang Subur.
\end{abstract}

International journal of linguistics, literature and culture @ 2020. This is an open access article under the CC BY-NC-ND license (https://creativecommons.org/licenses/by-nc-nd/4.0/).

Corresponding author:

I Made Juliarta,

Bali Dwipa University, Denpasar, Indonesia.

Email address: madejuliarta330@gmail.com

${ }^{a}$ Bali Dwipa University, Denpasar, Indonesia 


\section{Introduction}

The Good Earth is a novel written by Pearl S. Buck that was published in 1931 dramatizing family life in a Chinese village in the early 20th century. This novel was the best-selling novel in the United States in 1931 and 1932, won the Pulitzer Prize for Fiction in 1932 and was influential in Buck's winning the Nobel Prize for Literature in 1938 (Bowler et al., 1989; Guo et al., 1998). It was told that Buck, that grew up in China as the daughter of missionaries, wrote the book while living in China and drew on her first-hand observation of Chinese village life. It is stated that the novel was included in Life Magazine's list of the 100 outstanding books of 1924-1944. In 2004, the book returned to the bestseller list when it was chosen by the television host Oprah Winfrey for Oprah's Book Club. The Theatre Guild has written produced a Broadway stage adaptation in 1932 by the father and son playwriting team of Owen and Donald Davis. However, the film of The Good Earth, in 1937 which was based on the stage version, was more successful (Zhou et al., 2013; Ji, 2000). There are some reasons why the writer chose this novel as a data source.

This study is important to be conducted to figure out the form of an adverb of manner found in the novel The Good Earth and their translations into Bumi yang Subur. This study also tried to find out types of shifts of adverb of manner that occur in the translation of The Good Earth into Bumi yang Subur. The shift is interesting to be discussed to know that shifts sometimes occur in the translation process of relative clauses from English into Indonesian.

Brown \& Miller (1991), stated that the adverb of manner indicate how the event described by the verb. The adverb of manner shows how an action is performed. There are some variations in its form. Adverb of manner can be formed by adding ' $l y$ ' to an adjective sentence or word, but sometimes in other spelling. The adverb of manner can be formed in the form of adverb phrase and prepositional phrase. Analyzing sentence into its constituents is usually done in English. Using the constituent structure presentation, the adverb of manner can also be analyzed. The sentence structure could be known as syntactical identification by identifying and analyzing the constituent. The adverbial of manner can occur in some variations of its position. It occurs in the initial, medial, and end position (Broccias, 2011; Halliday, 1985; Huddleston \& Pullum, 2005; Thomson \& Martinet, 1980).

The analysis of the adverb of manner was done by a graduate student of the English Department. However, this analysis focused on the form and position of the adverbial of manner. Adverb of Manner is stated as to how the event described by the verb is carried out. Adverb of manner is unlike other adverbs that occur readily within the verb constituent. Adverb of Manner most naturally immediately follows the verb phrase, preceding other adverbs. There is a difference between adverb and adverbial. An adverb is stated as the name of a category and adverbial is the name of a function. An adverbial is stated as construction that modifies, or describes, verbs. It changes the meaning of that verb when an adverbial modifies a verb. There is also word groups considered to be adverbials. They can modify verbs. It can be seen, for example, a prepositional phrase. Brown \& Miller (1991), stated that adverbial is the name of a function. Adverbs typically have an adverbial function.

\section{Materials and Methods}

Adverb of Manner indicates the manner in the verb that is carried out. Adverb of manner, unlike other adverbs, occurs readily within the verb constituent. Adverb of Manner most naturally immediately follows the VP, preceding other adverbs. There is a difference between adverb and adverbial. An adverb is the name of a category and adverbial is the name of a function. An adverbial is a construction that modifies or describes, verbs. It changes the meaning of that verb when an adverbial modifies a verb. In the adverbial of manner, we can find prepositional phrases and adverbs of manner. According to Brown \& Miller (1991), adverbs of manner are the items that most readily spring to mind as examples of the class adverb, especially those formed by -ly suffix to a corresponding adjective form. The adverb of manner is VP modifiers. Adverbs take the form of adverbs, temporal noun phrases, and prepositional phrases. Prepositional phrases can happen in a variety of functions as the strict sub categorizer of a verb, as a VP adverbial and as a sentence adverbial. Adverbials can also take the form of a prepositional phrase. Brown \& Miller (1991), in his book A Linguistic Introduction in Sentence Structure, said that: Adverbs typically have an adverbial function. PPs may have the function of the adverb, but are not adverbs. We also noted that adverbs are modifiers and that to some extent the scope of the modification can be caught in constituent structure representations. Adverbs of manner illustrate the fact that the same category, PP, can occur in a variety of functions as the strict sub categorizer of a verb, as a VP adverbs and as a sentence adverbial (Pratama, 2015; Ernst, 2007; Johannessen, 2005; Haeberli \& Ingham, 2007; Doetjes, 2007). An adverb is called as an obligatory in a sentence. It is obligatory when it occurs after 
the class of copular verbs and after BE of a sentence. An adverb is required by the verb in order to form a well sentence structure and it can occur after a transitive verb.

Quirk \& Green baum (1973), stated that there are three positions of adverbs for the declarative form of the clause:

1. Initial Position (before the subject)

- Quickly, they did not leave for home (Quirk and Greenbaum, 1973:119)

- Nervously, the man opened the letter (Quirk and Greenbaum, 1973:119)

- With a great courtesy, she replied to my question (Quirk and Greenbaum, 1972:465)

2. Medial position:

M1: (a) Immediately before the first auxiliary or lexical be, or (b) between two auxiliaries or an auxiliary and lexical be.

M2: (a) Immediately before the lexical verb, or (b) in the case of lexical be, before the complement.

- He slowly drove the car into the garage (Quirk and Greenbaum, 1973:138)

- Tear gas was indiscriminately sprayed on the protesters (Quirk, 1972:465)

3. Final position: (a) after an intransitive verb, or (b) after any object or complement

- I paid for the book immediately (Quirk and Greenbaum, 1973:209)

This study is important to be conducted to figure out the types of adverbs of manner found in the novel The Good Earth and their translations into Bumi yang Subur. This study also tried to find out types of shifts of adverb of manner that occur in the translation of The Good Earth into Bumi yang Subur. The shift is interesting to be discussed to know that shifts sometimes occur in the translation process of relative clauses from English into Indonesian.

This study also uses the theory of translation to analyze the translation shift found in the sentence containing an adverb of manner. This study uses the theory proposed by Catford (1965) in analyzing the translation proses that occurred in the sentence containing adverb of manner. In the translation of shift, Catford (1965), stated that shift is the departure from formal correspondence in the process from the SL into the TL. The translation shift was made to get the natural equivalent of the source text message into the target text (1965: 76). Catford (1965), stated that it divides the shift in translation into two major types, level/rank shift, and category shift. What is meant by formal correspondence is any grammatical category in the target language which can be said to occupy the same position in the system of the target language as the given source language category in the source language system? Catford (1965), considers two kinds of shift: (1) Shift of level and (2) shift of category. The translation proses in this study were analyzed using the theory proposed by Catford (1965), meanwhile, the form of adverb of manner was analyzed using the theory proposed by Quirk.

\section{Results and Discussions}

Text I
This cauldron he filled partly full of water, dipping it with a half gourd from an earthen jar that stood near, but he dipped cautiously, for water was precious.(1) Ceret tadi diisinya penuh-penuh dengan air yang dituangkan dari buli-buli berbentuk labu yang diletakkan di dekat situ, tapi ia menuangkannya dengan hati- hati sebab air sangat berharga (7)

It can be seen from the sentence in the text I, that the adverbial of the manner in the constituent structure above can be filled in the form of adverb of manner. Cautiously is the adverb of manner which fills the position adverbial of manner. This adverb comes after the verb which is used to emphasize how he dipped. Cautiously is an adverb of manner which is derived from an adjective cautious and added by -ly suffix. In the process of the suffixation, the adverb of manner is formed by an adjective: cautious + (-ly) suffix. Therefore it becomes cautiously. An adverb of manner that fills the position adverbial of the manner in the constituent structure above is placed in the final position (I). An adverb of manner cautiously is translated into dengan hati-hati. It is placed after the verb dipped of the sentence. It can be seen from the text $\mathrm{I}$, that the verb in the source language is transferred into the verb in the target language but there is a shift in the structure, which changes the active verb into a passive verb. The verb filled is translated into diisi. The verb diisi is formed using the prefix -di to make the passive verb in Indonesian. The

Juliarta, I. M. (2020). Adverb of manner and its translations found in the novel "The Good Earth". International Journal of Linguistics, Literature and Culture, 6(3), 9-17. https://doi.org/10.21744/ijllc.v6n3.889 
structure shift occurs in this data since the verb diisi in the passive form is more appropriate to transfer the meaningfilled.

\section{Text II}

Then, after a hesitation, he suddenly lifted the jar and emptied all the water into the cauldron.(2)

Lalu, setelah ragu-ragu sebentar, sekonyong-konyong diangkatnya buli-buli tadi dan dituangkannya seluruh isinya ke dalam ceret itu. (7)

It can be seen from the sentence in-text II, that the adverbial of the manner in the constituent structure above can be filled in the form of adverb of manner. Suddenly is the adverb of manner which fills the position adverbial of manner. This adverb comes after the subject which is used to emphasize how he lifted the jar. Suddenly is an adverb of manner which is derived from an adjective sudden and added by -ly suffix. In the process of the suffixation, the adverb of manner is formed by sudden + (-ly) suffix. Therefore it becomes suddenly. An adverb of manner that fills the position adverbial of the manner in the constituent structure above is placed in the middle position (I). It is placed between the subject and the verb of the sentence. An adverb of manner suddenly is translated into sekonyongkonyong.

It can be seen from the text II, that the verb in the source language is transferred into the verb in the target language but there is a shift in the structure, which changes the active verb into a passive verb. The verb lifted is translated into diangkatnya. The verb diangkatnya is formed using the prefix -di to make the passive verb in Indonesian. The structure shift occurs in this data since the verb diangkatnya in the passive form is more appropriate to transfer the meaning lifted.

\section{Text III}

A small soft wind blew gently from the east, a wind mild and murmurous and full of rain.(1)

Semilir angin lembut bertiup dari arah timur, bisikannya begitu lembut dan mengandung titik air hujan. (1)

It can be seen from the sentence in-text II, that the adverbial of the manner in the constituent structure above can be filled in the form of adverb of manner. Gently is the adverb of manner which fills the position adverbial of manner. This adverb comes after the subject a small soft wind which is used to emphasize how a small soft wind blew from the east. Gently is an adverb of manner which is derived from an adjective gentle and added by -ly suffix. In the process of the suffixation, the adverb of manner is formed by gentle + (-ly) suffix. Therefore it becomes gently. An adverb of manner that fills the position adverbial of the manner in the constituent structure above is placed in the final position (I). It is placed after the verb of the sentence. It can be seen from the text III, that an adverb gently is translated into lembut.

\section{Text IV}

"I am coming," said Wang Lung, braiding his hair quickly and smoothly and weaving into the strands a tasseled black silk cord. (3)

"Sebentar" sahut Wang Lung, sambil menjalin kembali rambutnya dengan cepat dan cekatan dan mengunci untaiannya dengan pita sutra hitam.(11)

It can be seen from the sentence in-text IV, that the adverbial of the manner in the constituent structure above can be filled in the form of adverb of manner. Quickly is the adverb of manner which fills the position adverbial of manner. This adverb comes after the object of his hair which is used to emphasize how he is braiding his hair. Quickly is an adverb of manner which is derived from an adjective quick and added by -ly suffix. In the process of the suffixation, the adverb of manner is formed by a quick + (-ly) suffix. Therefore it becomes quickly. An adverb of manner that fills the position adverbial of the manner in the constituent structure above is placed in the final position (I). It is placed after the object of the sentence. It can be seen from the text III, that an adverb quickly is translated into dengan cepat.

It can be seen from the translation that there is a shift from a word into a phrase in the translation. A word braiding is translated into a phrase sambil menjalin kembali. According to the theory proposed by Catford, this type of translation shift is called a unit shift involving a change in rank. A Unit shift can occur when the translation 
equivalent of a source text unit at one rank. The unit shift is stated as the change in rank, that is, the departure from formal correspondence in which the translation equivalent of a unit at one rank in the source language. This type of shift is called unit shift, that is, a change in the lower rank.

Text V

"Then I will clean one ear and one nostril," rejoined the barber promptly. (6)

"Kalau begitu aku Cuma bisa membersihkan sebelah telingan dan sebelah lubang hidung", si tukang cukur menimpali dengan cerdik. (17)

It can be seen from the sentence in-text $\mathrm{V}$, that the adverbial of the manner in the constituent structure above can be filled in the form of adverb of manner. Promptly is the adverb of manner which fills the position adverbial of manner. This adverb comes after the object the barber used to emphasize how the subject rejoined the barber. Promptly is an adverb of manner which is derived from an adjective prompt and added by -ly suffix. In the process of the suffixation, the adverb of manner is formed by prompt + (-ly) suffix. Therefore it becomes promptly. An adverb of manner that fills the position adverbial of the manner in the constituent structure above is placed in the final position (I). It is placed after the object of the sentence. It can be seen from the text III, that an adverb promptly is translated into dengan cerdik.

It can be seen from the translation that there is a shift from a word into a phrase in the translation. A word then is translated into a phrase kalau begitu. According to the theory proposed by Catford, this type of translation shift is called a unit shift involving a change in rank. A Unit shift can occur when the translation equivalent of a source text unit at one rank. The unit shift is stated as the change in rank, that is, the departure from formal correspondence in which the translation equivalent of a unit at one rank in the source language. This type of shift is called unit shift, that is, a change in a higher rank.

\section{Text VI}

Now there is enough water to bring a crop to fruit, he said suddenly (3)

Nah, sekarang rupanya sudah ada air buat menyirami tumbuhan-tumbuhan kita itu (9)

We can see from the sentence in-text VI, that the adverb of the manner in the constituent structure above can be filled in the form of adverb of manner. Suddenly is the adverb of manner which fills the position adverbial of manner. This adverb comes after the verb said that is used to emphasize how he said. Suddenly is an adverb of manner derived from an adjective sudden and added by $-l y$ suffix. In the process of the suffixation, the adverb of manner is formed by prompt $+(-1 y)$ suffix. Therefore it becomes suddenly. An adverb of manner that fills the position adverbial of the manner in the constituent structure above is placed in the final position (I). It is placed after the object of the sentence. It can be seen from the text VI, that an adverb of manner suddenly is not translated.

It can be seen from the translation that there is a shift from a word into a phrase in the translation. A word there is translated into a phrase rupanya sudah ada. According to the theory proposed by Catford, this type of translation shift is called a unit shift involving a change in rank. A Unit shift can occur when the translation equivalent of a source text unit at one rank. The unit shift is stated as the change in rank, that is, the departure from formal correspondence in which the translation equivalent of a unit at one rank in the source language. This type of shift is called unit shift, that is, a change in the higher rank.

\section{Text VII}

He was supping loudly at his bowl (4)

Ia sedang asyik menghirup isi mangkuknya (12)

We can see from the sentence in-text VII, that the adverb of the manner in the constituent structure above can be filled in the form of adverb of manner. Loudly is an adverb of manner which fills the position adverbial of manner. This adverb comes after the verb supping that is used to emphasize how he was supping. Loudly is an adverb of manner derived from an adjective loud and added by -ly suffix. In the process of the suffixation, the adverb of manner is formed by loud $+(-1 y)$ suffix. Therefore it becomes loudly. An adverb of manner that fills the position adverbial of the manner in the constituent structure above is placed in the final position (I). It is placed after the verb of the sentence. It can be seen from the text VII, that an adverb of manner loudly is not translated.

Juliarta, I. M. (2020). Adverb of manner and its translations found in the novel "The Good Earth". International Journal of Linguistics, Literature and Culture, 6(3), 9-17. https://doi.org/10.21744/ijllc.v6n3.889 
It can be seen from the translation that there is a unit shift from a word into a phrase in the translation. A word supping is translated into a phrase sedang asyik menghirup. According to the theory proposed by Catford, this type of translation shift is called a unit shift involving a change in rank. A Unit shift can occur when the translation equivalent of a source text unit at one rank. The unit shift is stated as the change in rank, that is, the departure from formal correspondence in which the translation equivalent of a unit at one rank in the source language. This type of shift is called unit shift, that is, a change in the higher rank.

\section{Text VIII}

Perhaps he had better be newly shaven? It was scarcely sunrise yet? (4)

Bagaimana kalau ia mencukur sekali lagi? Matahari hampir terbit (12)

We can see from the sentence in-text VIII, that the adverb of the manner in the constituent structure above can be filled in the form of adverb of manner. Scarcely is an adverb of manner which fills the position adverbial of manner. This adverb comes after was that is used to emphasize how sunrise. Scarcely is an adverb of manner derived from an adjective scarce and added by $-l y$ suffix. In the process of suffixation, the adverb of manner is formed by a scarce + (-ly) suffix. Therefore it becomes scarcely. An adverb of manner that fills the position adverbial of the manner in the constituent structure above is placed in the middle position (I). It is placed after was. It can be seen from the text VIII, that an adverb of manner scarcely is translated into hampir

It can be seen from the translation that there is a unit shift from a word into a phrase in the translation. A word perhaps is translated into a phrase bagaimana kalau. According to the theory proposed by Catford, this type of translation shift is called a unit shift involving a change in rank. A Unit shift can occur when the translation equivalent of a source text unit at one rank. The unit shift is stated as the change in rank, that is, the departure from formal correspondence in which the translation equivalent of a unit at one rank in the source language. This type of shift is called unit shift, that is, a change in the higher rank.

\section{Text IX}

They were empty as yet and waiting for the rain. He smelled the air and looked anxiously at the sky (4)

Tunas-tunas itu belum sepenuhnya mekar dan nampaknya masih menunggu datangnya hujan. Cuping hidungnya mulai bekerja mencium bau udara saat itu, kemudian ia menengadah ke langit dengan perasaan harap cemas. (13)

We can see from the sentence in-text IX, that the adverb of the manner in the constituent structure above can be filled in the form of an adverb of manner. Anxiously is an adverb of manner which fills the position adverbial of manner. This adverb comes after the verb looked that is used to emphasize how he looked at the sky. Anxiously is an adverb of manner that is derived from an adjective anxious and added by -ly suffix. In the process of the suffixation, the adverb of manner is formed by anxious + (-ly) suffix. Therefore it becomes anxiously. An adverb of manner that fills the position adverbial of the manner in the constituent structure above is placed in the final position (I). It is placed after the verb looked. It can be seen from the text IX, that an adverb of manner anxiously is translated into dengan perasaan harap cemas.

It can be seen from the translation that there is a unit shift from a word into a phrase in the translation. A word anxiously is translated into a phrase dengan perasaan harap cemas. According to the theory proposed by Catford, this type of translation shift is called a unit shift involving a change in rank. It is stated that the unit shift can occur when the translation equivalent of a source text unit at one rank. The unit shift is stated as the change in rank, that is, the departure from formal correspondence in which the translation equivalent of a unit at one rank in the source language. This type of shift is called unit shift, that is, a change in the higher rank.

\section{Text X}

Wang Lung knew his father spoke well. Nevertheless, he had to struggle with his flesh before he could answer. And then he said violently. (12)

Wang Lung tahu teguran ayahnya itu ada benarnya juga. Meskipun demikian, ia masih harus bergulat dengan dirinya sendiri sebelum ia dapat menjawab. Lalu, ia menyahut lantang-lantang (15) 
We can see from the sentence in-text $\mathrm{X}$, that the adverb of the manner in the constituent structure above can be filled in the form of an adverb of manner. Violently is an adverb of manner which fills the position adverbial of manner. This adverb comes after the verb said that is used to emphasize how he said. Violently is an adverb of manner that is derived from an adjective violent and added by $-l y$ suffix. In the process of suffixation, the adverb of manner is formed by violent + (-ly) suffix. Therefore it becomes violently. An adverb of manner that fills the position adverbial of the manner in the constituent structure above is placed in the final position (I). It is placed after the verb said. It can be seen from the text $\mathrm{X}$, that an adverb of manner violently is translated into lantang-lantang.

It can be seen from the translation that there is a unit shift from a word into a phrase in the translation. A word violently is translated into a phrase lantang-lantang. According to the theory proposed by Catford, this type of translation shift is called a unit shift involving a change in rank. It is stated that the unit shift can occur when the translation equivalent of a source text unit at one rank. The unit shift is stated as the change in rank, that is, the departure from formal correspondence in which the translation equivalent of a unit at one rank in the source language. This type of shift is called unit shift, that is, a change in the higher rank.

\section{Text XI}

"Will you have more", asked the boy indifferently (6)

"Tambah lagi?", tanya bocah itu acuh tak acuh (19)

It can be seen from the sentence in-text XI, that the adverb of the manner in the constituent structure above can be filled in the form of an adverb of manner. Indifferently is an adverb of manner which fills the position adverbial of manner. This adverb comes after an object the boy that is used to emphasize how the boy asked. Indifferently is an adverb of manner that is derived from an adjective indifferent and added by -ly suffix. In the process of the suffixation, the adverb of manner is formed by indifferent $+(-1 y)$ suffix. Therefore it becomes indifferently. An adverb of manner that fills the position adverbial of the manner in the constituent structure above is placed in the final position (I). It is placed after an object to the boy. We can see from the text XI, that an adverb of manner indifferently is translated into acuh tak acuh.

It can be seen from the translation that there is a unit shift from a word into a phrase in the translation. A word indifferently is translated into a phrase acuh tak acuh. According to the theory proposed by Catford, this type of translation shift is called a unit shift involving a change in rank. It is stated that the unit shift can occur when the translation equivalent of a source text unit at one rank. The unit shift is stated as the change in rank, that is, the departure from formal correspondence in which the translation equivalent of a unit at one rank in the source language. This type of shift is called unit shift, that is, a change in the higher rank.

\section{Text XII}

"Bring me the tea", he said weakly to the boy (7)

"Bawakan aku teh", ujarnya lemah (20)

It can be seen from the sentence in-text XII, that the adverb of the manner in the constituent structure above can be filled in the form of adverb of manner. Weakly is an adverb of manner which fills the position adverbial of manner. This adverb comes after a verb said that is used to emphasize how he said. Weakly is an adverb of manner that is derived from an adjective weak and added by -ly suffix. In the process of the suffixation, the adverb of manner is formed by a weak + (-ly) suffix. Therefore it becomes weakly. An adverb of manner that fills the position adverbial of the manner in the constituent structure above is placed in the final position (I). It is placed after a verb said. We can see from the text XII, that an adverb of manner weakly is translated into lemah.

It can be seen from the translation that there is a unit shift from a phrase into a word in the translation. A phrase weakly to the boy is translated into a word lemah. According to the theory proposed by Catford, this type of translation shift is called a unit shift involving a change in rank. It is stated that the unit shift can occur when the translation equivalent of a source text unit at one rank. The unit shift is stated as the change in rank, that is, the departure from formal correspondence in which the translation equivalent of a unit at one rank in the source language. This type of shift is called unit shift, that is, a change in the lower rank.

Juliarta, I. M. (2020). Adverb of manner and its translations found in the novel "The Good Earth". International Journal of Linguistics, Literature and Culture, 6(3), 9-17. https://doi.org/10.21744/ijllc.v6n3.889 


\section{Text XIII}

"It's to be done", he said to himself desperately, and slowly he turned his way to the great gates (7)

"Mesti dikerjakan, ujarnya putus asa pada diri sendiri, dan perlahan-lahan ia melangkah menuju pintu gerbang megah itu. (20)

It can be seen from the sentence in-text XIII, that the adverb of the manner in the constituent structure above can be filled in the form of an adverb of manner. Slowly is an adverb of manner which fills the position adverbial of manner. This adverb comes after a verb said that is used to emphasize how he said. Slowly is an adverb of manner that is derived from an adjective slow and added by -ly suffix. In the process of the suffixation, the adverb of manner is formed by slow + (-ly) suffix. Therefore it becomes slowly. An adverb of manner that fills the position adverbial of the manner in the constituent structure above is placed in the final position (I). It is placed after a verb said. We can see from the text XIII, that an adverb of manner slowly is translated into perlahan-lahan.

It can be seen from the translation that there is a unit shift from a word into a phrase in the translation. An adverb slowly is translated into a phrase perlahan-lahan. According to the theory proposed by Catford, this type of translation shift is called a unit shift involving a change in rank. It is stated that the unit shift can occur when the translation equivalent of a source text unit at one rank. The unit shift is stated as the change in rank, that is, the departure from formal correspondence in which the translation equivalent of a unit at one rank in the source language. This type of shift is called unit shift, that is, a change in higher rank

\section{Conclusion}

This study uses the theory of translation to analyze the translation of the shift found in the sentence containing an adverb of manner. This study uses the theory proposed by Catford (1965) in analyzing the translation process that occurred in the sentence containing an adverb of manner. In the translation of shift, Catford (1965), stated that shift is the departure from formal correspondence in the process from the SL into the TL. The translation shift was made to get the natural equivalent of the source text message into the target text (1965: 76). Based on the research, there is a shift in translating the source text into the target language.

\section{Conflict of interest statement}

The author declared that he has no competing interests.

Statement of authorship

The author has a responsibility for the conception and design of the study. The author has approved the final article.

Acknowledgments

I am grateful to two anonymous reviewers for their valuable comments on the earlier version of this paper. 


\section{References}

Bowler, J., Lilley, T. J., Pittam, J. D., \& Wakeling, A. E. (1989). Novel steroidal pure antiestrogens. Steroids, 54(1), 71-99. https://doi.org/10.1016/0039-128X(89)90076-7

Broccias, C. (2011). Motivating the flexibility of oriented-ly adverbs. Motivation in Grammar and the Lexicon, 7188.

Brown, K., Miller, J., \& Miller, J. E. (1991). Syntax: a linguistic introduction to sentence structure. Psychology Press.

Catford, J. C. (1965). A linguistic theory of translation: An essay in applied linguistics. Oxford University Press.

Doetjes, J. (2007). Adverbs and quantification: Degrees versus frequency. Lingua, 117(4), 685-720. https://doi.org/10.1016/j.lingua.2006.04.003

Ernst, T. (2007). On the role of semantics in a theory of adverb syntax. Lingua, 117(6), 1008-1033. https://doi.org/10.1016/j.lingua.2005.03.015

Guo, Z. Y., Li, D. Y., \& Wang, B. X. (1998). A novel concept for convective heat transfer enhancement. International Journal of Heat and Mass Transfer,41(14), 2221-2225. https://doi.org/10.1016/S0017-9310(97)00272-X

Haeberli, E., \& Ingham, R. (2007). The position of negation and adverbs in Early Middle English. Lingua, 117(1), 125. https://doi.org/10.1016/j.lingua.2005.08.001

Halliday, M. A. K. (1985). An Introduction to Functional Grammar, Edward Arnold, London. Google Scholar.

Huddleston, R., \& Pullum, G. K. (2005). A student's introduction to English grammar. Cambridge University Press.

Ji, S. (2000). 'Face'and polite verbal behaviors in Chinese culture. Journal of pragmatics, 32(7), 1059-1062. https://doi.org/10.1016/S0378-2166(99)00068-5

Johannessen, J. B. (2005). The syntax of correlative adverbs. Lingua, 115(4), $419-443$. https://doi.org/10.1016/j.lingua.2003.09.009

Pratama, P. B. (2015). The roles held by the suffix -mente in deriving spanish adjective with reference to adverb. International Journal of Linguistics, Literature and Culture, 1(1), 34-37.

Quirk, R., \& Greenbaum, S. (1973). A concise grammar of contemporary English. Harcourt School.

Thomson, A. J., \& Martinet, A. V. (1980). A practical English grammar. Oxford University Press.

Zhou, Q. B., Zhang, J., \& Edelheim, J. R. (2013). Rethinking traditional Chinese culture: A consumer-based model regarding the authenticity of Chinese calligraphic landscape. Tourism Management, 36, 99-112. https://doi.org/10.1016/j.tourman.2012.11.008

Juliarta, I. M. (2020). Adverb of manner and its translations found in the novel "The Good Earth". International Journal of Linguistics, Literature and Culture, 6(3), 9-17. https://doi.org/10.21744/ijllc.v6n3.889 